\title{
CLINICAL, RADIOGRAPHICAL AND HISTOPATHOLOGICAL EVALUATION OF AMNIOTIC MEMBRANE ALLOGRAFT PULPOTOMY IN PRIMARY TEETH
}

\author{
Talat Mohamed Beltagy* and Sarah Yasser **
}

\begin{abstract}
Background: A novel dehydrated Human Amniotic Membrane (dHAM) allograft is a placental based scaffold that has been widely used in a verity of medical fields due to its unique regenerative ability in wound healing. Objective: To evaluate clinically, radiographically, and histopathologically the efficacy of dehydrated Human Amniotic Membrane allograf as a pulpotomy agent in primary teeth. Materials and Methods: I- Clinical and radiographical evaluation: This split-mouth, randomized clinical trial was conducted on 40 deeply carious primary molars indicated for pulpotomy. They were selected from 16 healthy children aged 4-8 years. They were randomly allocated into two equal groups (20 molars/each). Group 1: dHAM pulpotomy in one quadrant and Group 2: Formocresol (FC) pulpotomy in the contralateral. All molars were treated with the conventional pulpotomy technique. All patients were recalled for clinical and radiographical evaluation at 3,6, and 9 months post-treatment. II- Histopathological assessment: A total of 30 healthy lower first primary molars and canines that indicated for serial extraction were selected for histopathological evaluation. The dHAM allograft and formocresol pulpotomies were performed (12 teeth/each group), where the other 6 teeth were used as a control. Six teeth from each experimental group were extracted at post-treatment intervals; one and three months. The samples were prepared for histopathological evaluation. All data were subjected to the exact test. Fisher exact test and Monte Carlo test were also used. The level of significance was set at $\mathrm{P}<0.05$. Results: I-Clinical and radiographic results: The overall clinical success rates for both groups were $100 \%$, whereas the overall radiographic success rates for $\mathrm{dHAM}$ and FC groups were $100 \%$ and $85 \%$, respectively, but the difference was not statistically significant $(\mathrm{p}>0.05)$. II-Histopathological results: The overall evaluation at 1-month interval showed better histopathological criteria for dHAM group than FC group, but the difference was only significantly better on the degree of the inflammatory response $(\mathrm{p}<0.05)$. Whereas at 3 -month interval, the dHAM group displayed significantly better histopathological criteria compared to the FC group $(\mathrm{p}<0.05)$. Conclusion: The dHAM allograft with its regenerative, biologic biocompatibility properties and its ability to deliver growth factors has shown successful outcome comparable to gold standard formocresol. Hence, it can be recommended as an alternative promising pulpotomy agent.
\end{abstract}

KEYWORDS: Amniotic membrane; Formocresol; primary molars; Pulpotomy.

\footnotetext{
* Associate Professor of Pediatric Dentistry, Faculty of Dentistry, Kafrelsheikh University.

**Lecturer of Oral Biology, Faculty of Dentistry, Tanta University.
} 


\section{INTRODUCTION}

One of the primary pedodontics goals is the preservation of arch integrity ${ }^{(1)}$, so, all attempts were made to maintain the natural tooth as it is considered to be the ideal space maintainer ${ }^{(2)}$. The objective of pulpotomy is to preserve the pulp vital instead of replacing it with an inert endo-filling and maintain the teeth integrity \& function, till their time of normal exfoliation ${ }^{(3)}$.

Formocresol (FC) was regarded as the gold standard pulpotomy medicament for primary teeth (4), but it has several side effects apart from not being ideal pulpotomy agent and concern have been raised by several investigators over using it in humans. Therefore, different alternatives with a wider safety margin have been proposed ${ }^{(1,5,6)}$.

Despite of the recent advances in synthetically based biomaterials, researches still reported their mild to moderate cytotoxicity on pulp. Hence, it is important to propose new biologically based therapeutics directed at preserving pulp vitality ${ }^{(7)}$, forming biological tissue ${ }^{(8)}$, and neutralizing the side effects of previously used synthetically based biomaterials ${ }^{(9)}$.

Recently, novel biologically based materials have been developed from the placenta or other gestational tissues like the umbilical cord with highly rich stem cell reservoirs ${ }^{(10)}$. Amniotic membrane (AM) is a foetal membranous sac forming the innermost layer of the placenta. It is a bi-layered membrane consists of amnion and chorion. Amnion consists of 3 distinct thin layers: an epithelial monolayer (closest to the foetus), a basement membrane and avascular mesenchymal stromal matrix (containing mesenchymal stem cells) that composed of 3 adjacent but distinct layers: outermost spongy, middle fibroblastic and inner compact.

Although it is a thin membrane (70-180 $\mu \mathrm{m}$ thick), it is remarkably elastic and formidable strong natural biological barricade protecting the fetus from trauma and bacterial infection ${ }^{(11,12)}$. In contrast, the chorion is 3-4 times thicker than amnion and consists of a reticular, basement membrane, and trophoblastic layers ${ }^{(13)}$. Both membranes play important roles in embryo's overall development, embryo's nourishment, breathing and seepage ${ }^{(11)}$.

Amniotic membrane matrix contains plenteous growth factors (GFs) including basic-fibroblast growth factor (b-FGF), nidogen growth factor (NGF), keratinocyte growth factor (KGF), epidermal derived growth factor (EDGF), and transforming GF-beta growth factor (TGF- $\beta$ ) which promote tissue regeneration ${ }^{(14)}$. These GFs mimic the stem cell niche for ex vivo growth and provide a natural healing environment. It acts as a structural scaffold supporting proliferation, differentiation, and regeneration due to presence of fibronectin, laminins, proteoglycans, collagen types I, III, IV, V and VI, elastin, nidogen, and hyaluronic acid in its stromal layer, and act as an excellent candidature for a native scaffold in tissue engineering ${ }^{(15)}$.

Furthermore, it secretes nutrient factors (16), promotes cell migration, adhesion, differentiation, and suppresses the semiallogenic immune response against the foetus ${ }^{(17)}$. In addition, it has a biological, anti-inflammatory (similar to cortisone and steroids shots), anti-fibrotic, anti-microbial (including beta-defensins), anti-scarring, anti-angiogenic and analgesic properties that make it a unique therapy for wound care and ideal substrate for supporting the growth of mesenchymal progenitor cells via prolonging their lifespan ${ }^{(18-21)}$.

It is used in xenotransplant or allotransplant due to its ability to promote cellular growth and attachment with the lack of its immunogenicity and toxicity; it was first reported by Davis since $1910^{(22)}$ in skin transplantation. Also, it has been used successfully for over a decade in a wide range of surgical application, biological wound dressing, vestibuloplasty ${ }^{(23)}$, ophthalmic reconstructive surgery ${ }^{(24,25)}$, an adhesion barrier in the spine, and in-ear and orthopedic surgery ${ }^{(26)}$. It is easily obtained, processed, transported, and prepared in different forms for 
clinical use like fresh, dried, frozen, freeze derived irradiated, stabilized amniotic and cryopreserved membranes ${ }^{(27)}$.

Amnion-based products have a proven rate of success in the field of dentistry since 1990s, when first demonstrated safety and efficacy in pre-and clinical studies ${ }^{(28)}$. It is commercially available for dentistry in $2008^{(21)}$. The dehydrated or cryopreserved membrane is used for retaining the majority of the natural (fibrillar and membranous) collagens, maintaining the composition of GFs and bioactive molecules found in natural and unprocessed placental tissues, and increasing stability and shelf life of the product ${ }^{(29-31)}$.

Subsequently, it has been used successfully as a guided tissue regeneration, in the correction of gingival recession, root conditioning, management of wounds in the oral cavity and its reconstruction, repair of oro-antral communication, haemostatic, and wound dressing agent ${ }^{(32,33)}$. Yet, this study aimed to evaluate clinically, radiographically and histopathologically, the success of dried Human Amniotic Membrane (dHAM) allograft as a pulpotomy agent in primary teeth.

\section{MATERIALS AND METHODS}

Ethical approval of this research was documented from the Ethics Committee, Faculty of Dentistry, Kafrelsheikh University. All children's parents participating in this study were thoroughly informed of the objective and procedures of the research and informed consents were obtained from them.

This prospective, split-mouth, randomized clinical trial was carried out on 40 lower deeply carious $\left(1^{\text {st }}\right.$ and/or $\left.2^{\text {nd }}\right)$ primary molars indicated for pulpotomy. They were selected from 16 healthy children who attended the Out-Patient Clinic of the Pediatric Dentistry, Faculty of Dentistry, Kafrelsheikh University. Each child had at least two matched bilateral lower carious primary molars requiring pulpotomy. The patients aged 4-8 years, with their mean age of $6.48 \pm 0.6$.
Before the clinical intervention, medical and dental histories as well as clinical and radiographic examination were carried out. A split-mouth design was used, where one side was randomly selected for one group intervention and the contralateral side for the other. The dHAM and formocresol pulpotomies were performed (20 teeth/each group). To maintain clinical standardization, all clinical interventions in this study were performed by an operator.

\section{Clinical inclusion criteria ${ }^{(1,34)}$}

- All children were cooperative with no underlying medical, physical or learning disabilities.

- Absence of any clinical signs and symptoms of pulp degeneration such as a history of spontaneous pain, pain on percussion, swelling, pathological mobility, or sinus tract.

- Mechanical pulp exposure is larger than pinpoint.

- The pulpotomized primary molar would be restorable with a stainless steel crown.

- Any haemorrhage from the amputated pulp stumps should be easily controlled within 5 minutes by using a pledget of sterile moist cotton pellets.

- No children were excluded based on gender and social status.

\section{Radiographic inclusion criteria $^{(1,34)}$}

- The carious lesion approximating the pulp.

- The recruited molars should have a normal radiographic appearance with healthy supporting tissues.

- The presence of at least $2 / 3$ of the root remains.

- No evidence of pathological root resorption (external and/or internal), widening of periodontal ligament (PDL), and periapical or furcal radiolucency. 


\section{Pulpotomy procedure}

A preoperative periapical radiograph was carried out by the XCP extension cone paralleling technique. After achieving profound local anaesthesia using 27-gauge disposable short needle and syringe loaded with carpule [1.8 mm Mepivacaine $\mathrm{HCl} 2 \%$ (Mepecaine-L, Alexandria Co. for Pharmaceuticals, Alexandria, Egypt)] and rubber dam isolation with saliva ejector. One sitting conventional pulpotomy intervention was performed for both groups. Caries, soft debris and dentin were removed using large slow-speed round bur. Then, a diamond round bur mounted in a water-cooled high-speed handpiece was used for deroofing the pulp chamber and removing overhanging dentin. The inflamed coronal pulp tissues were amputated using a sharp large sterile spoon excavator till the entrance of the roots followed by gentle debridement with normal saline irrigation, and then dried with sterile cotton pellets. Initial pulpal haemostasis was achieved using a sterile moisturized cotton pellet with saline that was gently pressed against the amputated pulp stumps for 5 minutes.

\section{Group 1 (dHAM group):}

After achieving haemostasis, a previously trimmed double layer of sterile processed human allograft tissue (StreiShield II dehydrated dual-layer dental amnion patch, VeraGraft, DentalProdX, Texas, USA) was soaked in saline for a minute ${ }^{(36)}$, then placed directly on the pulp stumps using sterile tweezers and adjusted to the entire floor of the pulp chamber. Fig 1A-L.

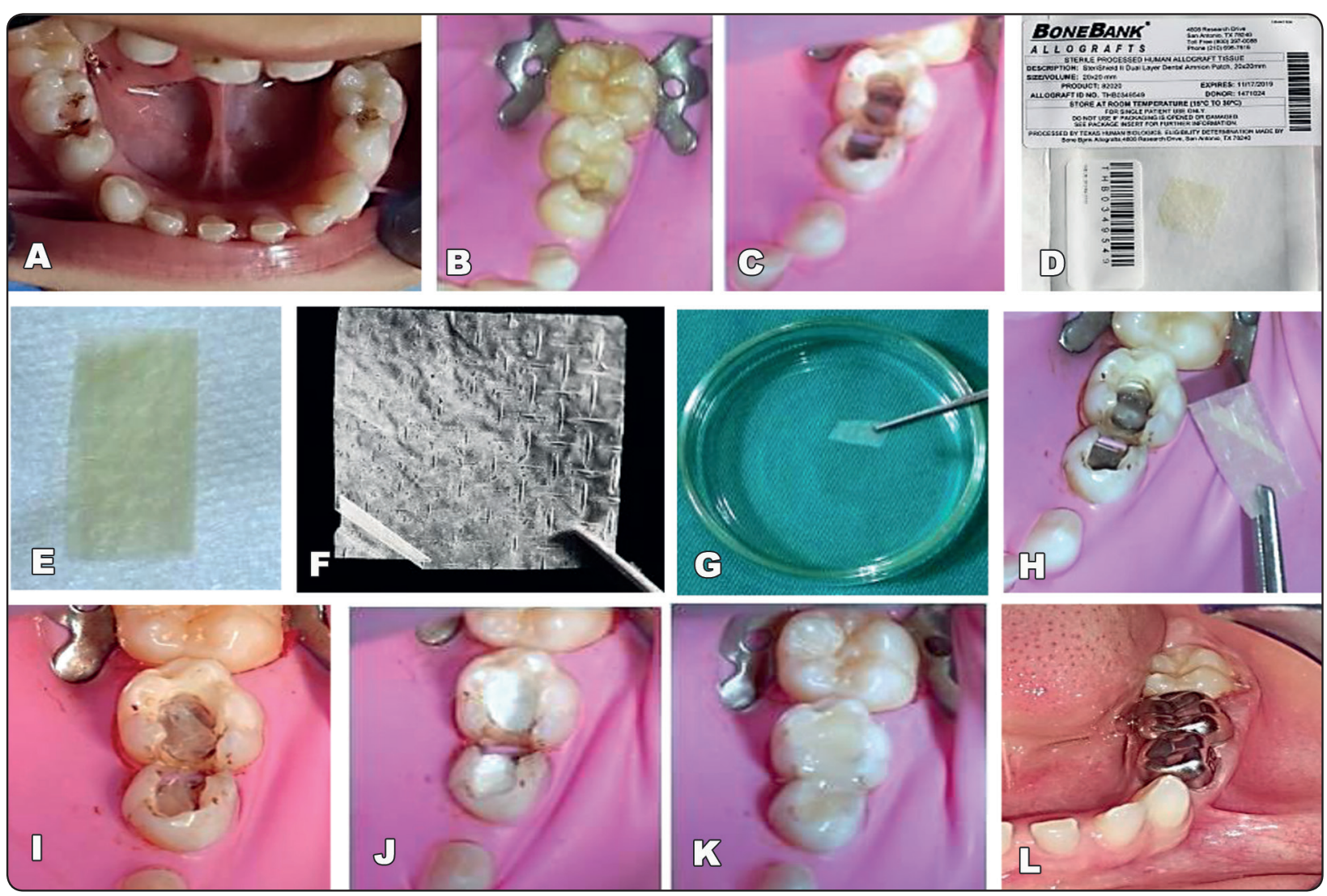

Fig (1A-L) Preoperative photograph showing carious lower primary molars indicated for pulpotomies (A). Left (LT) side was treated with dHAM pulpotomy. After rubber dam isolation and haemostasis of the pulp stumps (B, C). StreiShield II duallayer dental amnion patch $20 X 20 \mathrm{~mm}(\mathrm{D}, \mathrm{E})$. High magnification of the membrane (F). The membrane was soaked for a minute in a sterile glass petri dish containing saline solution $(\mathrm{G})$ and then carried out the membrane to cover the pulp stumps $(\mathrm{H}, \mathrm{I})$. The cavities were sealed with IRM and covered with glass ionomer restorative (J, K). Final restoration with stainless steel crowns (L). 


\section{Group 2 (Formocresol group):}

In this control group, a sterile cotton pellet was moistened with 1:5 concentration formocresol (Buckley's Formocresol, Sultan Healthcare, Englewood, NJ, USA). The excess was removed by squeezing the pellet twice between gauze and then placed on the amputated pulp for 5 minutes ${ }^{(37)}$. Fig 2A-H.

The prepared cavities of all pulpotomized molars were sealed with a layer of intermediate dressing (IRM; Dentsply, Milford, DE, USA) and subsequently covered with glass-ionomer restorative (Ketac Molar, 3M ESPE, USA). An immediately postoperative radiograph was taken, and all treated molars were finally restored with suitable-sized stainless steel primary molar crowns (Kids Crown, Shinhung Dental, Seoul, Korea).

All patients were directed to maintain a good oral hygiene and were recalled for clinical and radiographic evaluation at 3,6 , and 9 months postoperatively.

The criteria for clinical success were the absence of pain, tenderness to percussion, abscess, softtissue swelling or sinus tract, pathologic tooth mobility and premature exfoliation at recall visit.
Whereas, the radiographic criteria for success were: normal PDL space, the absence of pathological internal and/or external root resorption, and no signs of any radiolucency in the furcation and/or the periapical area. If a pulp canal obliteration or pulp stone occurred, it was reported but not considered as a treatment failure ${ }^{(35)}$. The overall success rate, both clinically and radiographically, was assessed for each patient. If a pulpotomized treated tooth deviated from one of the success criteria, it was regarded as a treatment failure.

\section{Histopathological evaluation}

A total number of thirty healthy lower primary canines and first molars that formerly planned for serial extraction were selected from children who attended the Out-Patient Clinic of Pediatric Dentistry, Faculty of Dentistry, Kafrelsheikh University.

The dHAM allograft and formocresol pulpotomy procedures were performed as mentioned previously (12 teeth/each group) (figs $3 \& 4$, respectively), and the other six teeth were used as a control. Six teeth from each experimental group were extracted at post-treatment intervals; one and three months. All cases received lingual arch to utilize the Leeway space for premolars' eruption.

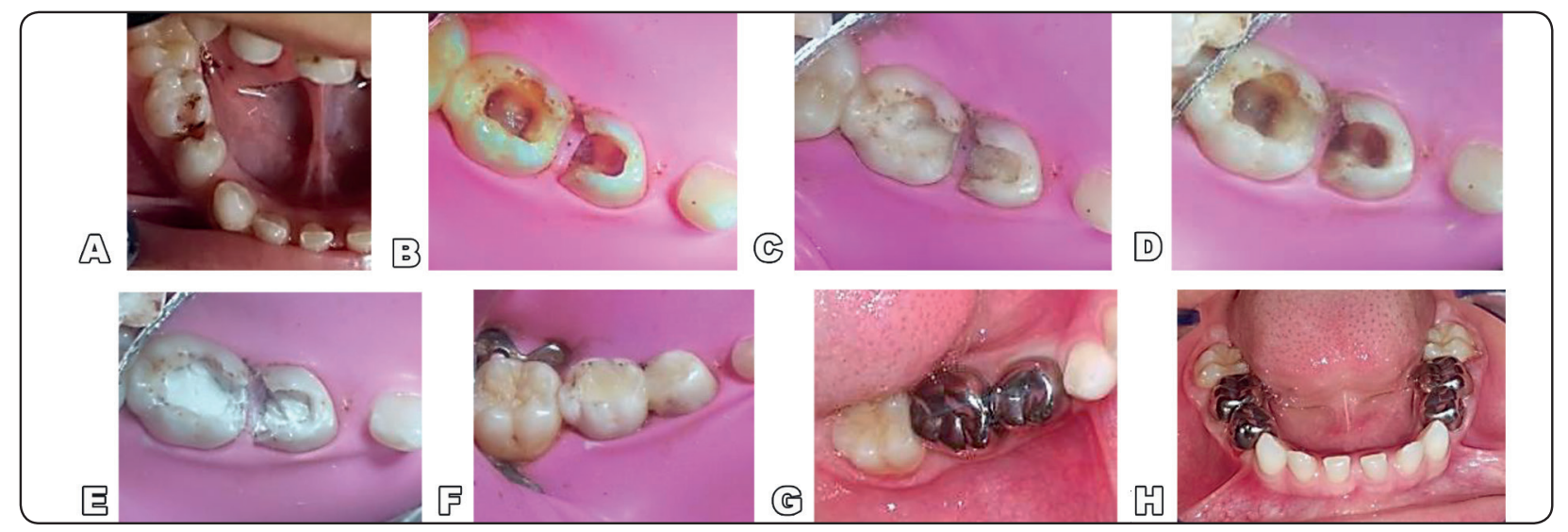

Fig. (2A-H) Continue the case of fig 1: Preoperative photograph of lower right (RT) primary molars indicated for FC pulpotomy (A). The prepared cavities after removal of pulp chambers (B). Coronal pulp haemostasis using moist sterile cotton pellets (C). The pulp stumps post-FC application (D). The cavities were sealed with IRM (E), covered with glass ionomer restorative $(\mathrm{F})$, and finally restored with stainless steel crowns $(\mathrm{G}, \mathrm{H})$. 


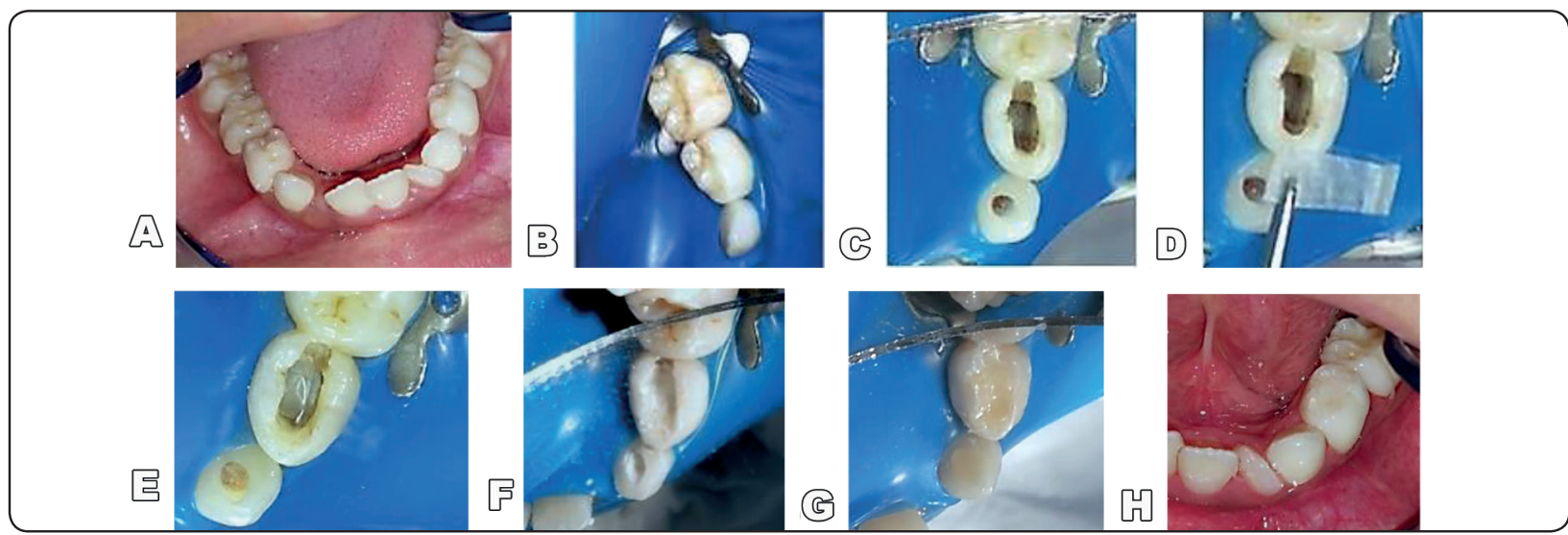

Fig (3A-H) Preoperative photograph of a case with gross arch length deficiency indicated for serial extraction due to impacted and rotated lower permanent lateral incisors (A). Clinical steps of dHAM allograft pulpotomy on LT primary canine and $1^{\text {st }}$ primary molar $(\mathrm{B}-\mathrm{H})$. Before and after pulp chambers removal (B, C). Before and after application of dHAM (D, E). The cavities were sealed with IRM and covered with glass ionomer restorative (F-H).

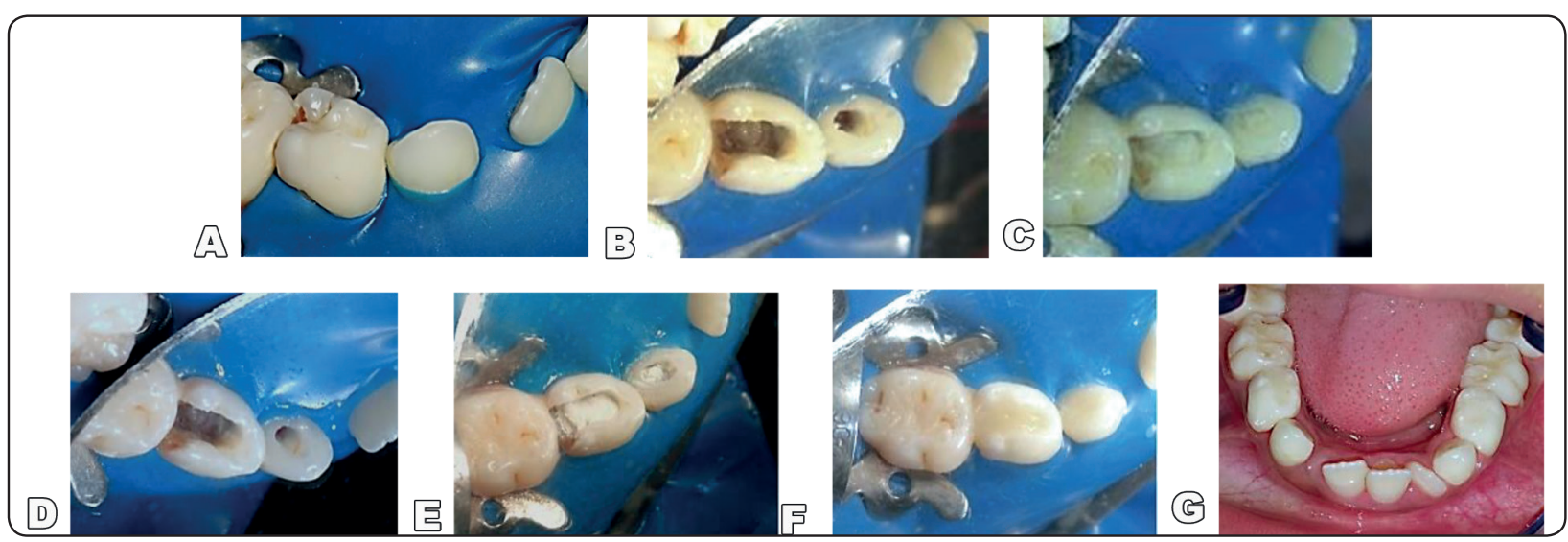

Fig (4A-G) Continue the case of fig 3: Clinical steps of FC pulpotomy on the lower RT primary canine and $1^{\text {st }}$ primary molar. After rubber dam isolation and pulp chambers removal (A, B). Haemostasis of coronal pulp tissues (C). The pulp stumps post-FC application (D). The cavities were sealed with IRM (E) and covered with glass ionomer restorative (F). Final restoration (G).

\section{Histopathological examination}

The extracted samples were fixed in $10 \%$ formalin buffered solution for 10 days and then decalcified in $10 \%$ Ethylene diamine tetraacetic acid (EDTA) for 8 weeks after sealing the apical foramina with sticky wax. The decalcified specimens were dehydrated through gradually ascending concentrations of ethanol, and embedded in paraffin blocks.

Serial longitudinal sections at $4-\mu \mathrm{m}$ thickness using a microtome were obtained, stained with hematoxylin and eosin $(\mathrm{H} \& \mathrm{E}){ }^{(38)}$, and then they were consequently examined histologically under light microscope (Eclipse 80i; Nikon, Tokyo, Japan).

All sections were histopathologically analyzed blindly according to the modified criteria of Hasheminia et al. (39) and Songsiripradubboon et al. ${ }^{(40)}$ for soft tissue organization, the degree of pulpal inflammation, tissues necrosis, and dentinal bridge formation.

\section{Histopathological criteria:}

\section{According to soft tissue organization:}

1- Normal or almost normal organization under the exposure area, tissue-material interface or under 
the formed dentinal bridge. The presence of newly formed collagen fibers and well organized odontoblast-like cells.

2- Partial loss of normal organization under the exposure area, tissue-material interface, or dentinal bridge. Some collagen fibers and few cells appeared away from the exposure area.

3- Complete loss of normal organization and some free spaces were present.

\section{According to the degree of pulpal inflammation}

1- Absence or little of inflammation: 1-3 inflammatory cells under exposure area or the dentin bridge.

2- Mild inflammation: 4-10 inflammatory cells under the exposure area or dentin bridge.

3- Moderate inflammation: 11-50 inflammatory cells under the exposure area or dentin bridge.

4- Severe inflammation: $>50$ inflammatory cells or the presence of micro abscesses under the exposure area or the formed dentin bridge.

\section{According to dentinal bridge formation:}

0 - Absence of coverage.

1- Partial coverage of the exposure area.

2- Complete coverage of the exposure area.

\section{According to pulp tissues necrosis:}

0 - Absent.

1- Present.

\section{Statistical Analyses:}

All data were statistically analyzed using the SPSS (Statistical Package for the Social Sciences) program, version 20.0 (IBM, Illinois, Chicago, IL, USA). All data were subjected to the exact test. Fisher exact test was used for $2 \mathrm{X} 2$ observations and Monte Carlo test was used for observations with more than $2 \mathrm{X} 2$ observations. The level of significance was set at $\mathrm{P}<0.05$.

\section{RESULTS}

In the clinical and radiographic part of this study, a total of 40 lower primary molars from 16 children ( 9 boys and 7 girls aged $4-8$ years, mean age $6.48 \pm 0.6$ ) indicated for pulpotomies were included. The pulpotomies were performed using dHAM allograft versus FC, whereas other 30 pulpotomies were performed on sound lower primary molars and canines for histopathological evaluation. All patients were available for clinical and radiographic evaluation till the end of the study.

\section{I- Clinical evaluation}

At the end of the study, both dHAM allograft and formocresol groups showed 100\% clinical success rates. The difference was not significant between them at any period of recall intervals $(\mathrm{p}>0.05 \%)$. Table 1 and fig 5 .

TABLE (1) Clinical assessment of dHAM and FC pulpotomies during recall intervals.

\begin{tabular}{|c|c|c|c|c|c|c|}
\hline \multirow{3}{*}{ Clinical parameters } & \multicolumn{6}{|c|}{ Follow-up period } \\
\hline & \multicolumn{2}{|c|}{3 months } & \multicolumn{2}{|c|}{6 months } & \multicolumn{2}{|c|}{9 months } \\
\hline & dHAM & FC & dHAM & FC & dHAM & FC \\
\hline Pain & $0 / 20$ & $0 / 20$ & $0 / 20$ & $0 / 20$ & $0 / 20$ & $0 / 20$ \\
\hline Pathologic tooth mobility & $0 / 20$ & $0 / 20$ & $0 / 20$ & $0 / 20$ & $0 / 20$ & $0 / 20$ \\
\hline Abscess & $0 / 20$ & $0 / 20$ & $0 / 20$ & $0 / 20$ & $0 / 20$ & $0 / 20$ \\
\hline Fistula/Sinus & $0 / 20$ & $0 / 20$ & $0 / 20$ & $0 / 20$ & $0 / 20$ & $0 / 20$ \\
\hline premature exfoliation & $0 / 20$ & $0 / 20$ & $0 / 20$ & $0 / 20$ & $0 / 20$ & $0 / 20$ \\
\hline $\mathbf{p}^{*}$ & \multicolumn{2}{|c|}{1.000} & \multicolumn{2}{|c|}{1.000} & \multicolumn{2}{|c|}{1.000} \\
\hline
\end{tabular}




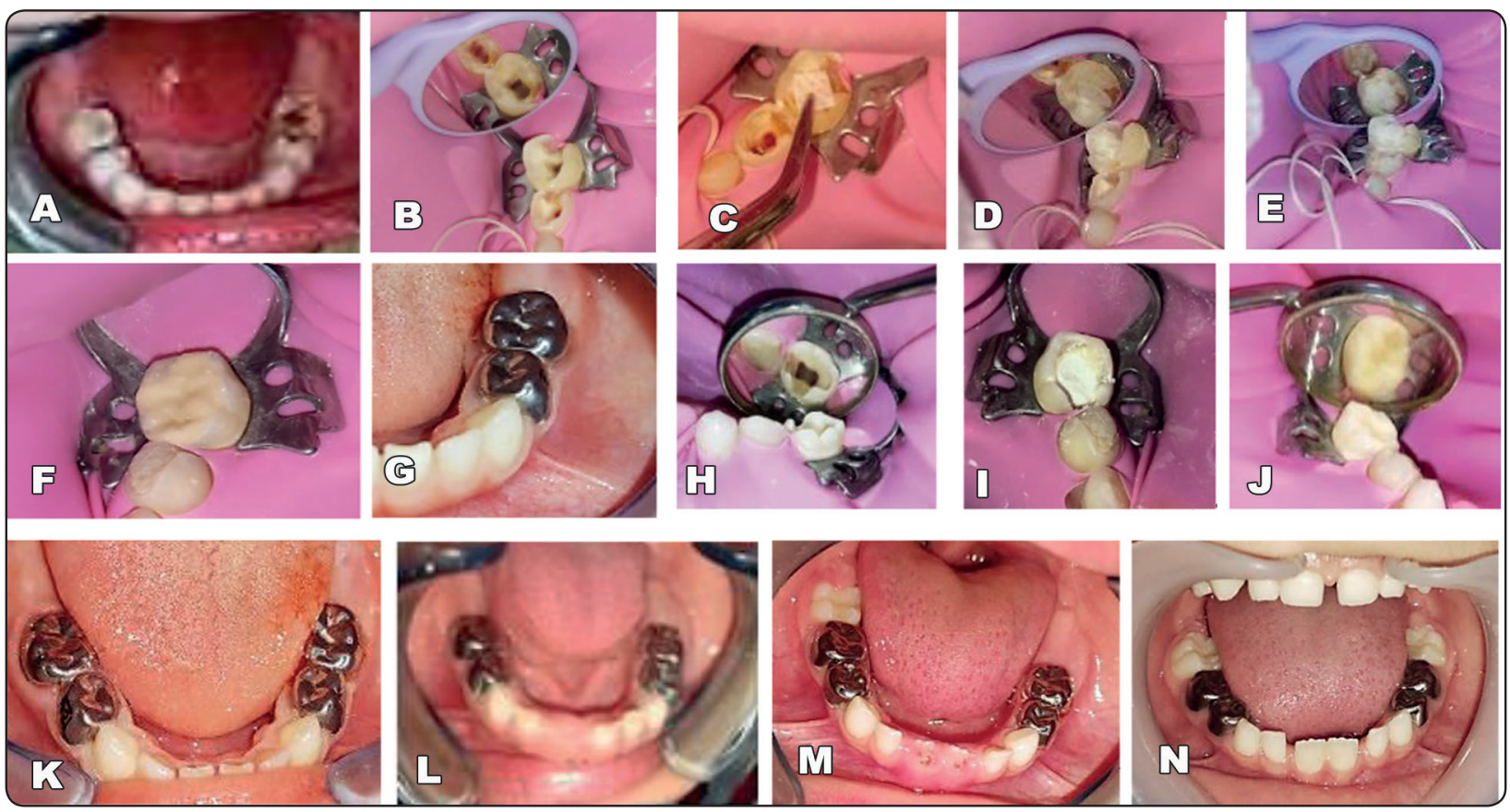

Fig (5A-N) Preoperative photograph of a child showed deep carious lower $2^{\text {nd }}$ primary molars (A) indicated for dHAM (LT side B-J) and FC (RT side H-J) pulpotomies. The case after permanent restoration with stainless steel crowns (K). Follow-up at 3,6 , and 9 months without clinical manifestations (L-N).

\section{II- Radiographical evaluation:}

The overall radiographic success rates for dHAM allograft and FC groups were 100\% and $85 \%$, respectively. Figs 6-12.

The dHAM group revealed no abnormal radiographic findings during the recall intervals (tables $2 \& 3$ and figs $6 \& 7$ ). While in FC group, 3 primary molars $(15 \%)$ showed radiographic failures (tables 2\&3). One of them (5\%) showed pathologic root resorption at 6-month which increased at 9-month of recall (fig 8), other one (5\%) recorded periapical radiolucency associated with external root resorption at the mesio-cervical third of distal root during 6 and increased at 9 months of recall (fig 9). The last tooth (5\%) displayed furcal radiolucency at 9-month of recall (fig 10). The three failure cases were asymptomatic till the end of recall, and no clinical interference was undertaken for them. Accordingly, no statistically significant differences were noted between them at any time of recall $(\mathrm{p}>0.05 \%)$.

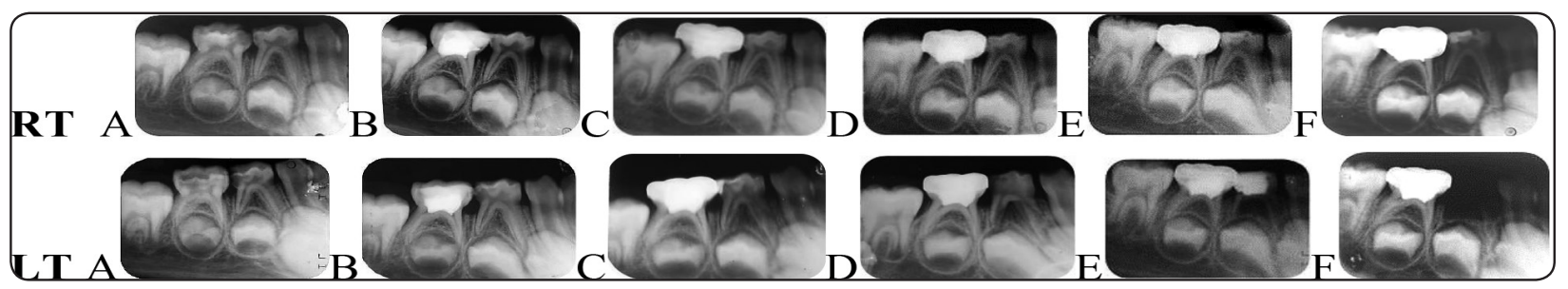

Fig (6) Both groups: Preoperative intraoral peri-apical (IOPA) radiographs showing deep carious lesions approaching the healthy pulp of lower $2^{\text {nd }}$ primary molars indicated for pulpotomy (A), RT side (FC group) and LT side (dHAM group). IOPA radiographs post-pulpotomies filling (B) and stainless steel crown restorations (C). Post-IOPA radiographs showed no parameter changes at 3,6 and 9 months (D-F). 
TABLE (2) Radiographical assessment of the success and failure rates in both groups during recall intervals.

\begin{tabular}{|c|c|c|c|c|c|c|}
\hline \multirow{4}{*}{ Groups } & \multicolumn{6}{|c|}{ Follow-up period } \\
\hline & \multicolumn{2}{|c|}{3 months } & \multicolumn{2}{|c|}{6 months } & \multicolumn{2}{|c|}{9 months } \\
\hline & Success & Failure & Success & Failure & Success & Failure \\
\hline & No $(\%)$ & No $(\%)$ & No $(\%)$ & No $(\%)$ & No $(\%)$ & No $(\%)$ \\
\hline dHAM & $20(100)$ & $0(---)$ & $20(100)$ & $0(---)$ & $20(100)$ & $0(---)$ \\
\hline FC & $20(100)$ & $0(---)$ & $18(90)$ & $2(10)$ & $17(85)$ & $3(15)$ \\
\hline $\mathrm{p}^{*}$ & \multicolumn{2}{|c|}{1.000} & \multicolumn{2}{|c|}{1.000} & \multicolumn{2}{|c|}{1.000} \\
\hline
\end{tabular}

No $(\%)=$ Number of teeth and percentage for each group $\quad$ dHAM = dehydrated Human Amniotic Membrane $\quad F C=$ Formocresol *Significant at $p<0.05$

TABLE (3) Radiographical assessment of dHAM and FC pulpotomies during recall intervals.

\begin{tabular}{|c|c|c|c|c|c|c|}
\hline \multirow{3}{*}{ Radiographic parameters } & \multicolumn{6}{|c|}{ Follow-up period } \\
\hline & \multicolumn{2}{|c|}{3 months } & \multicolumn{2}{|c|}{6 months } & \multicolumn{2}{|c|}{9 months } \\
\hline & DHAM & FC & dHAM & FC & dHAM & FC \\
\hline Widening of the periodontal ligament & $0 / 20$ & $0 / 20$ & $0 / 20$ & $0 / 20$ & $0 / 20$ & $0 / 20$ \\
\hline $\begin{array}{c}\text { Pathologic root resorption ( internal and/or } \\
\text { external root resorption) }\end{array}$ & $0 / 20$ & $0 / 20$ & $0 / 20$ & $2 / 20$ & $0 / 20$ & $0 / 19$ \\
\hline Furcal radiolucency & $0 / 20$ & $0 / 20$ & $0 / 20$ & $0 / 20$ & $0 / 20$ & $1 / 20$ \\
\hline Periapical radiolucency & $0 / 20$ & $0 / 20$ & $0 / 20$ & $1 / 20 * *$ & $0 / 20$ & $0 / 19$ \\
\hline Pulp canal obliteration/pulp stone & $0 / 20$ & $0 / 20$ & $0 / 20$ & $0 / 20$ & $0 / 20$ & $0 / 20$ \\
\hline $\mathbf{p}^{*}$ & \multicolumn{2}{|c|}{1.000} & \multicolumn{2}{|c|}{1.000} & \multicolumn{2}{|c|}{1.000} \\
\hline
\end{tabular}

No= 20 teeth $\quad$ dHAM = dehydrated Human Amniotic Membrane $\quad F C=$ Formocresol $\quad *$ Significant at $p<0.05 * *=A$ tooth containing two parameters (any tooth has more than 1 parameter, it considers one failure case).

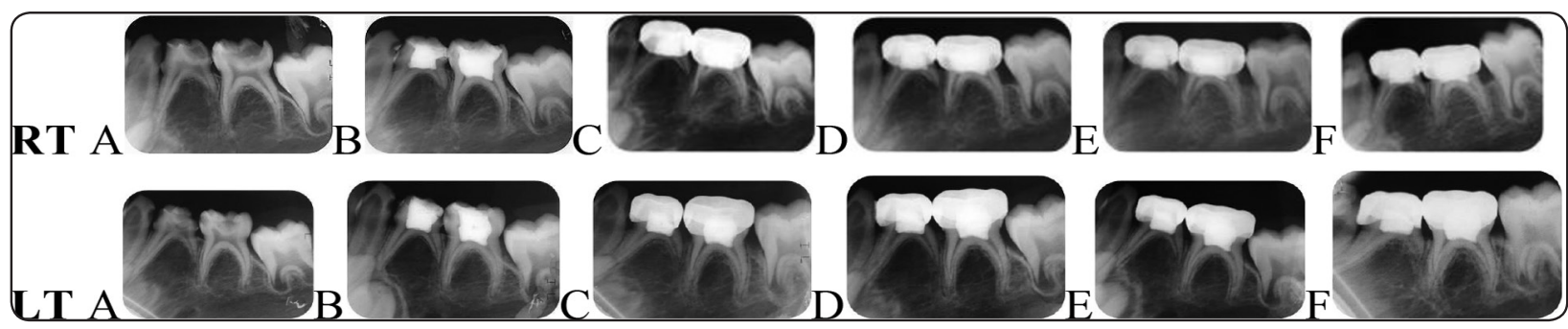

Fig (7) Both groups [RT side (FC group) and LT side (dHAM group)]: Preoperative IOPA radiographs showing deep carious lesions approaching the healthy pulp of lower primary molars indicated for pulpotomies, that associated with congenital missing of their successors (A). IOPA radiographs showing post-pulpotomies filling (B) and stainless steel crown restorations (C). Post-IOPA radiographs showing no parameter changes during recall intervals (D-F). 


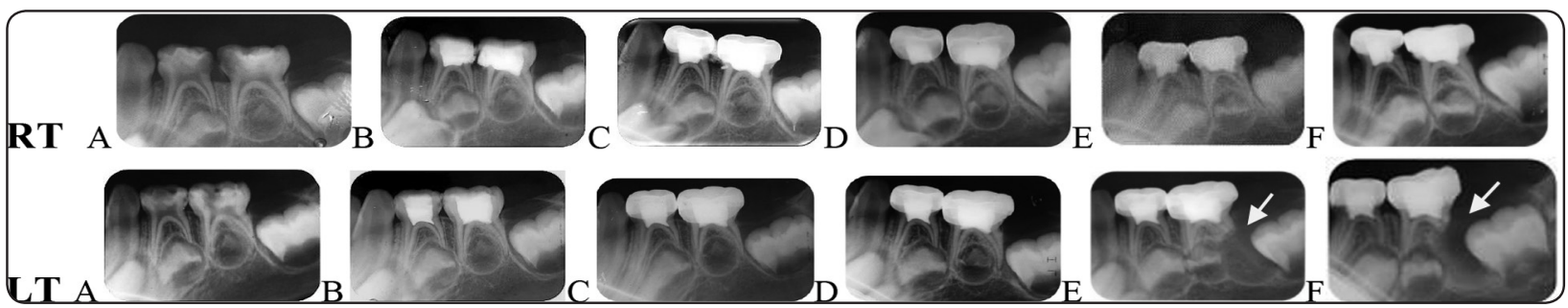

Fig (8) Preoperative IOPA radiographs showing deep caries of lower primary molars indicated for dHAM pulpotomy (RT side) and FC pulpotomy (LT side) (A). IOPA radiographs post-dHAM pulpotomy (B) and stainless steel crown restorations (C). IOPA radiographs showing no parameter changes at 3, 6 and 9 months of recall (D-F). LT side (FC group): IOPA radiographs post-pulpotomy treatment (B) and stainless steel crown restorations (C). IOPA radiograph showing no parameter changes at 3 months (D). Pathologic distal root resorption (arrow) was detected at 6-month that increased at 9-month of recall (E, F).

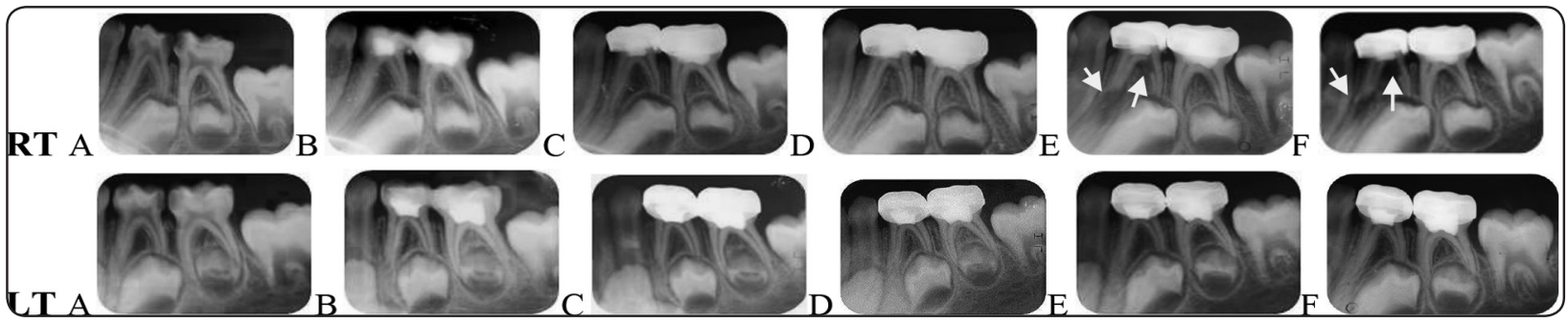

Fig (9) Preoperative IOPA radiographs with deep caries of lower primary molars indicated for FC pulpotomy (RT side) and dHAM pulpotomy (LT side) (A). IOPA radiographs post-pulpotomy filling and stainless steel crown restorations for both groups (B, C). RT side (FC group): Post-IOPA radiograph showing no radiographic changes at 3-month (D), but at 6 and 9 months, the $1^{\text {st }}$ primary molar displayed pathologic external root resorption and periapical radiolucency (arrows) (E-F). LT side (dHAM group) showing no radiographic changes during recall (C-F).

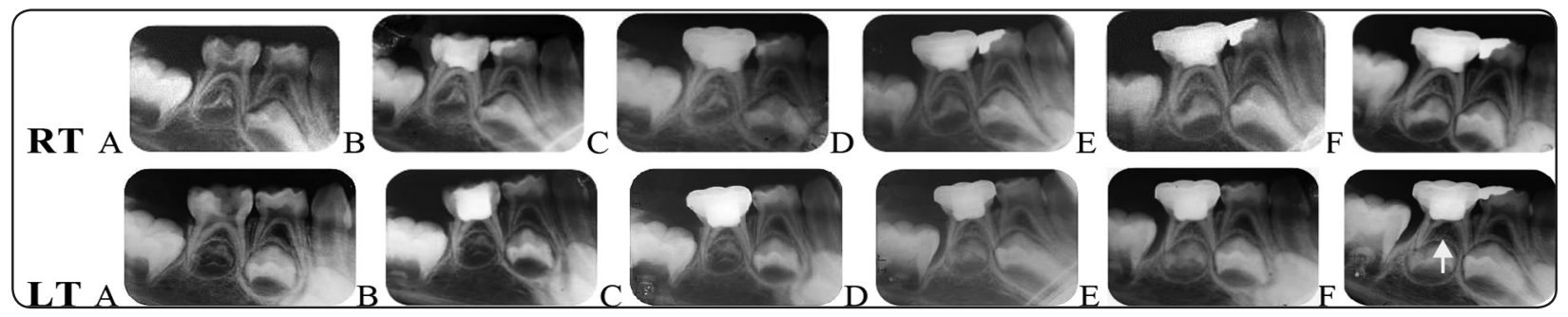

Fig (10) Preoperative IOPA radiographs with deep caries of lower $2^{\text {nd }}$ primary molars indicated for dHAM pulpotomy (LT side) and FC pulpotomy (RT side) (A). IOPA radiographs post-pulpotomies filling and stainless steel crown restorations for both groups (B, C). RT side (dHAM) group: Post-IOPA radiographs showing no parameter changes at 3, 6, and 9 months of recall (D, F). LT side (FC group): Post-IOPA radiographs showing no parameters changes at 3 and 6 months, but at 9-month of recall, furcal radiolucency was observed (arrow) (F). 


\section{III- Histopathological assessment:}

Twenty four pulpotomized primary $1^{\text {st }}$ molars and canines with 6 untreated controlled teeth were evaluated histopathologically at post-treatment interval of 1 month and 3 months. Data in tables 4 and 5 showed that the overall evaluation at 1-month interval showed better histopathological criteria for dHAM group than the FC group, but the difference was only significantly better on the degree of the pulpal inflammatory response $(\mathrm{p}<0.05)$. Whereas at 3-month interval, the dHAM group displayed significantly better histopathological criteria compared to the FC group $(\mathrm{p}<0.05)$.

The control group showed normal cellular organization of the pulpal tissues without inflammations, and there was a regular arrangement of the odontoblastic cell layers (fig 11).

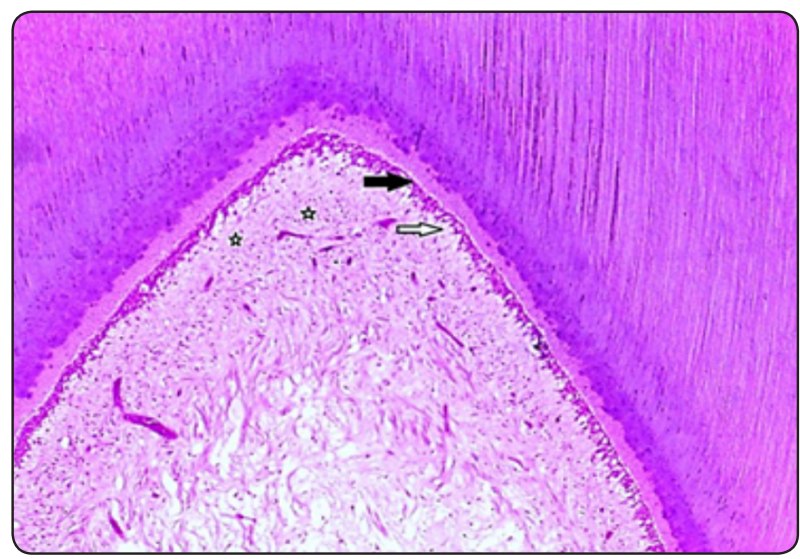

Fig (11) Light micrograph illustrates the histological features of control dental pulp with normal architecture, intact odontoblastic layer (black arrow), clear cell-free zone (white arrow) and cell-rich zone (white stars) $[\mathrm{H} \& \mathrm{E}$ stain, original magnification $\mathrm{x} 100]$.

TABLE (4) The overall histopathologic results of pulpal response of the experimental groups at 1 month post-treatment.

\begin{tabular}{|c|c|c|c|c|c|c|c|c|c|c|c|c|}
\hline \multirow{2}{*}{ Groups } & \multicolumn{3}{|c|}{$\begin{array}{c}\text { Soft tissue } \\
\text { organization }\end{array}$} & \multicolumn{4}{|c|}{ Degree of inflammation } & \multicolumn{2}{|c|}{$\begin{array}{l}\text { Tissues } \\
\text { necrosis }\end{array}$} & \multicolumn{3}{|c|}{ Bridge formation } \\
\hline & 1 & 2 & 3 & 1 & 2 & 3 & 4 & 0 & 1 & 0 & 1 & 2 \\
\hline dHAM No $=6$ & 4 & 2 & 0 & 5 & 1 & 0 & 0 & 6 & 0 & 2 & 4 & 0 \\
\hline FC No=6 & 0 & 3 & 3 & 0 & 0 & 4 & 2 & 5 & 1 & 6 & 0 & 0 \\
\hline$P$ value & \multicolumn{3}{|c|}{0.083} & \multicolumn{4}{|c|}{$0.001 *$} & \multicolumn{2}{|c|}{1.000} & \multicolumn{3}{|c|}{0.061} \\
\hline
\end{tabular}

No: 12 teerh dHAM = dehydrated Human Amniotic Membrane FC=Formocresol *Significant at $p<0.05$

TABLE (5) The overall histopathologic results of pulpal response of the experimental groups at 3 months post-treatment.

\begin{tabular}{|c|c|c|c|c|c|c|c|c|c|c|c|c|}
\hline \multirow{2}{*}{ Groups } & \multicolumn{3}{|c|}{$\begin{array}{c}\text { Soft tissue } \\
\text { organization }\end{array}$} & \multicolumn{4}{c|}{ Degree of inflammation } & \multicolumn{3}{c|}{$\begin{array}{c}\text { Tissues } \\
\text { necrosis }\end{array}$} & \multicolumn{3}{c|}{ Bridge formation } \\
\cline { 2 - 14 } & 1 & 2 & 3 & 1 & 2 & 3 & 4 & 0 & 1 & 0 & 1 & 2 \\
\hline dHAM No=6 & 5 & 1 & 0 & 5 & 1 & 0 & 0 & 6 & 0 & 0 & 1 & 5 \\
\hline FC No=6 & $\mathbf{0}$ & 1 & 5 & 0 & 0 & 0 & 6 & 1 & 5 & 6 & 0 & 0 \\
\hline P value & \multicolumn{3}{|c|}{$0.001 *$} & \multicolumn{4}{|c|}{$0.001 *$} & & \multicolumn{2}{|c|}{$0.015^{*}$} & \multicolumn{2}{|c|}{$0.001 *$} \\
\hline
\end{tabular}

No: 12 dHAM = dehydrated Human Amniotic Membrane FC= Formocresol *Significant at $p<0.05$ 


\section{Group 1: (dHAM group):}

It was found that the dHAM treated group showed a better soft tissue organization, a lower degree of pulpal inflammation and no tissue necrosis at both 1 and 3 months intervals. At 1 month, most of the cases (66.7\%) displayed normal pulpal soft tissue organization (fig 12) with partial dentin bridge formation (fig 13). $83.3 \%$ of the cases showed no signs of inflammation except one case $(16.7 \%)$ expressed a mild degree of tissue inflammation. At 3 months post-treatment intervals $(83.3 \%)$ of the dHAM group demonstrated normal pulp tissue architecture, no signs of inflammation with the formation of complete dentin bridge that is formed by osteodentin type (fig 14). Interestingly an active zone of predentin and dentin formation was observed near the osteodentine bridge areas in most cases (fig 15). On the other hand, only one case $(16.7 \%)$ failed to maintain normal tissue architecture with mild inflammation and partial dentin bridge formation.

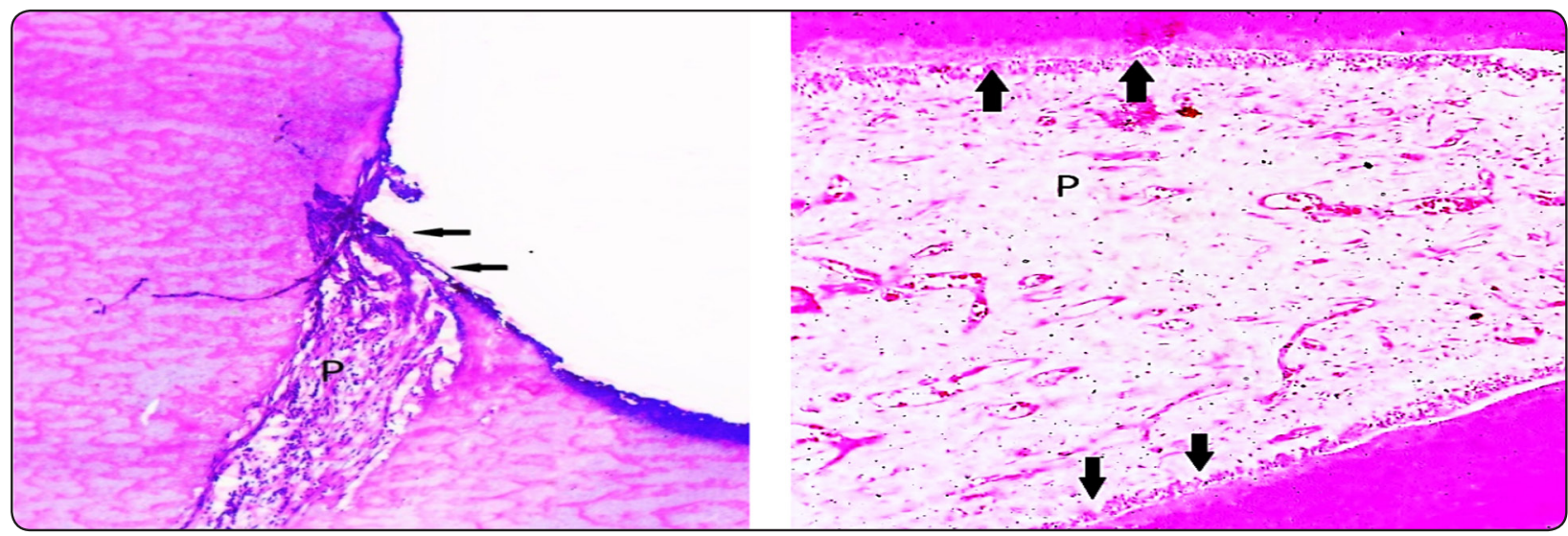

Fig (12 RT) Light micrograph illustrates the histological features of dental pulp at 1 month follow up of dHAM group. This group shows pulp (P) with normal architecture, no inflammatory infiltration, no fibrosis, and an intact odontoblastic layer is observed (black arrows) [H\&E stain, original magnification x200]. Fig (13 LT) Light micrograph illustrates the histological features of dental pulp $(\mathrm{P})$ at 1 month follow-up of dHAM group. This group shows formation of partial dentin bridge (black arrows) [H\&E stain, original magnification $\mathrm{x} 100]$.

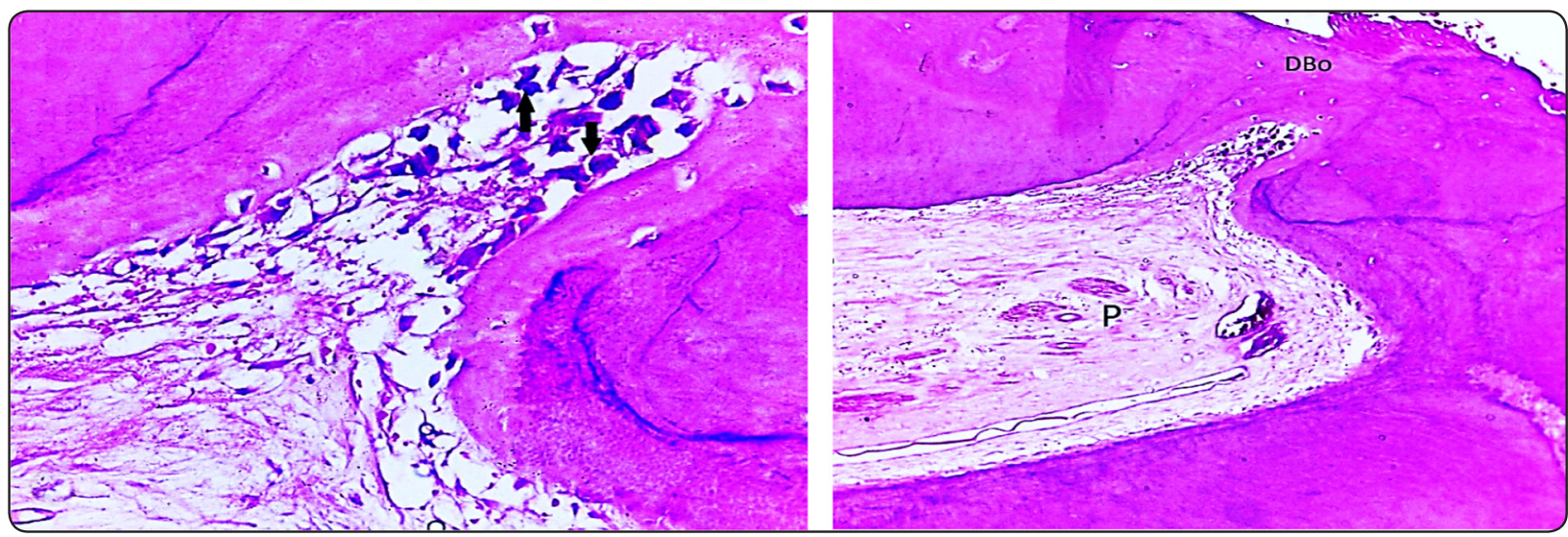

Fig (14 RT) Light micrograph illustrates the histological features of dental pulp at 3 months follow up of dHAM group. This group shows normal pulpal structure $(\mathrm{P})$, no inflammatory infiltration and the formation of complete dentin bridge of osteodentin type (DBo) [H\&E stain original magnification x100]. Fig (14 LT) A higher magnification showing the formation of complete dentin bridge of osteodentin type (DBo), areas of tubular dentin and odontoblasts like cells (black arrows) [H\&E stain original magnification $\mathrm{x} 400]$. 


\section{Group 2: (FC group)}

In contrast to dHAM group, the FC group at 1-month interval showed abnormal soft tissue architecture in all cases. Half of the cases represented mild tissue destruction, while the other half demonstrated severe destruction with loss of odontoblastic cell layer (fig 16) and signs of internal dentin resorption (fig 17). Only one case demonstrated signs of tissue necrosis. All

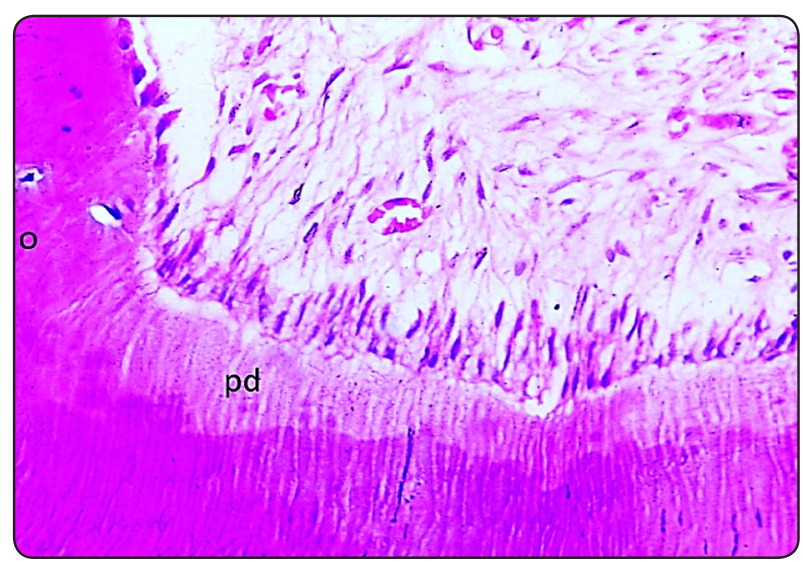

Fig (15) Light micrograph illustrates the histological features of dental pulp at 3 months follow-up of dHAM group. This group shows areas of active dentin formation with wide predentin layer ( $\mathrm{pd}$ ) next to the formed osteodentin (o) [H\&E stain, original magnification $\mathrm{x} 400]$.

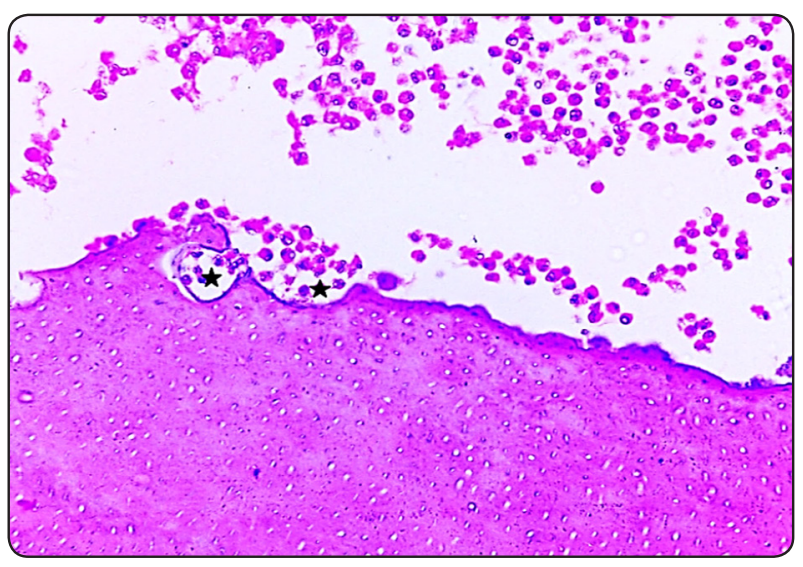

Fig (17) Light micrograph illustrates the histological features of dental pulp at 1 month follow up of FC treated group. This group shows complete loss of odontoblastic cell layer, signs of pulpal degeneration and resorbed dentin surface (black stars) [H\&E stain, original magnification $\mathrm{x} 100]$. cases showed either moderate $(66.7 \%)$ or severe inflammatory response $(33.3 \%)$. There was a complete absence of dentin bridge formation in any of the examined slides. At 3-month interval, all cases demonstrated severe inflammatory reaction with most of them (83.3\%) showing severe tissue destruction with areas of tissue necrosis (fig 18). There was a complete absence of dentin bridge formation in all cases.

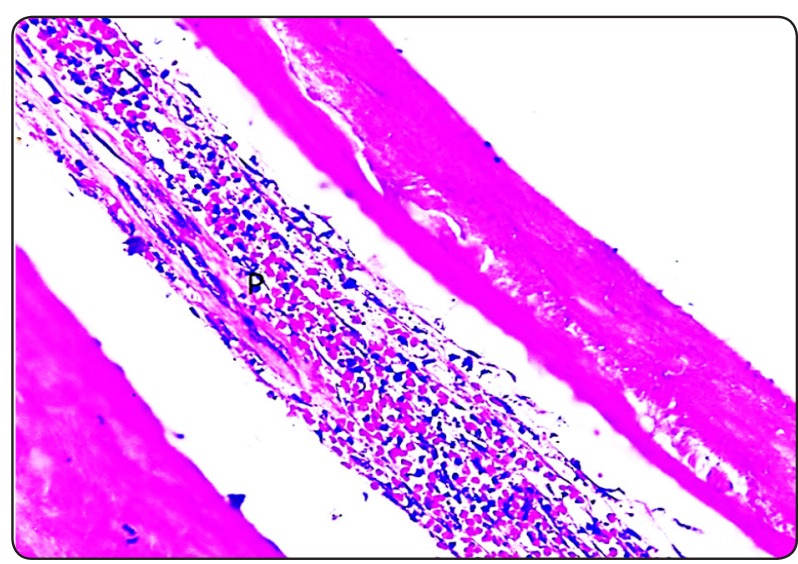

Fig (16) Light micrograph illustrates the histological features of the dental pulp (P) at 1 month follow up of FC treated group. This group shows the loss of odontoblastic cell layer with abundant inflammatory cells $[H \& E$ stain, original magnification $\mathrm{x} 100]$.

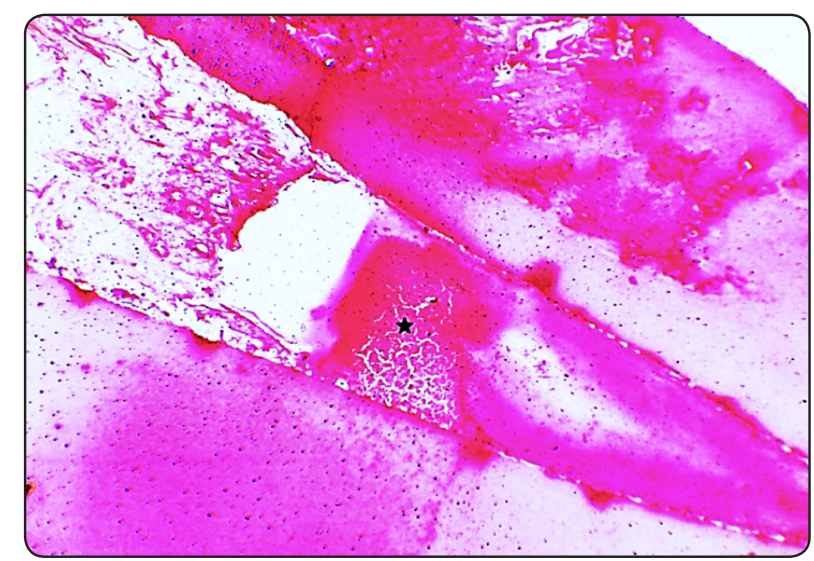

Fig (18) Light micrograph illustrates the histological features of dental pulp at 3 months follow up of FC treated group. Pulp cells are no longer identifiable, tissue architecture is completely lost with necrotic foci (black stars) [H\&E stain, original magnification $\mathrm{x} 100]$. 


\section{DISCUSSION}

One of the most important vital factors responsible for pulpotomy success is the right choice of material used. According to meta-analysis and several systematic reviews, no strong evidence was found to identify one superior pulpotomy agent or technique. Therefore, it is important to propose newly inherently biocompatible and biologically based therapeutics to maintain the pulp vital rather than the synthetically based one ${ }^{(5)}$.

Nowadays, the attention and awareness of researchers are directed toward regenerative medicine, as it seems to be the ideal and successful approach to pulp therapy since its main principle is to mimic the physiological events of growth and development ${ }^{(41)}$.

Among the most widely used regenerative materials is the placental tissue. The high biocompatibility and low immunogenicity with the presence of several GFs (PDGF-BB, TGF-beta1, bFGF, VEG and TIMP) and cytokines/chemokines in amnion recommends its use as alternative or a tissue engineering scaffold in a variety of medical fields, including ophthalmology, gynaecology, urology, pediatrics, neurosurgery, plastic surgery, oral/maxillofacial surgery, wound care ${ }^{(42-44)}$.

Furthermore, the amnion structure is similar to the pulp tissue in several aspects. Both of them are soft connective tissues with the presence of monolayer cells in their peripheral zone, i.e., odontoblasts in the pulp tissue and epithelial cells in $\mathrm{AM}$, which gives a notable distinguished similarity ${ }^{(42)}$. Moreover, accessibility and lower costs can be considered as advantages of the amniotic membrane in comparison with other membranes. This encourages the use of the novel dHAM allograft in this study as a pulpotomy regenerative agent for primary teeth versus formocresol.

The age group selected in this study ranged from 4-8 years to avoid the lack of cooperation of children under 4 years while above 8 years of age; more than
3/4 of primary roots may show physiologic root resorption ${ }^{(39)}$.

In the current study, formocresol was used as a control group, since it is still the most popular and gold standard pulpotomy medicament for primary teeth. This may be due to its ease of use, availablility, bactericidal effect, and better fixative efficacy with high clinical and radiographic outcomes ${ }^{(36,45)}$.

Recently, various AM allografts are commercially available for clinical use. Different techniques for their preservation have a significant impact on their physical properties and biochemical composition and thus can affect their clinical efficacy. The dHAM showed higher GF retention, bioavailability and superior healing capacity compared with the cryopreserved type ${ }^{(30)}$. Also, it is safer as it is gamma-irradiated, reducing any chances of cross infections ${ }^{(36)}$. Hence, dHAM was given preferrance to be used in this study.

In this study, the dHAM was soaked in normal saline solution for a minute to release the bounded GFs that declined after $96 \mathrm{hrs}$, whereas collagenase digestion releases the remaining bound GFs from the pulp tissue as observed by Koob et al. ${ }^{(46)}$, who also reported that HAM retained its tensile strength across a wide range of temperatures for at least 72 hrs.

Our results revealed a $100 \%$ clinical success rate for both groups. This may be attributed to correct protocol, careful diagnosis with complete tooth isolation, and proper manipulation of the material under aseptic conditions ${ }^{(47)}$. Although a rare number of publications in the literature reporting on amnion pulpotomy, consistent with our survey, this outcome agrees with the study of Prasad et al. (36) who reported $100 \%$ clinical success for both groups. The high clinical success of amnion in this study may be due to its regenerative abilities and the higher biocompatibility ${ }^{(48,49)}$. This is consistent with the explanation of Malhotra et al. ${ }^{(18)}$, Chen et al. (20), solomon et al. ${ }^{(50)}$ and Lullove (31) who 
attributed their clinical success in management of ocular surface defects and chronic wound repair to the several advantages of AM as having numerous GFs and cytokines and having immunomodulatory, anti-inflammatory, anti-fibrotic, anti-microbial, anti-scarring, anti-angiogenic and analgesic effects. Also, it provides a source of stem cells and provides a protein-enriched matrix to facilitate cell migration ${ }^{(51)}$. Its stromal matrix shows a marked pro-inflammatory cytokines suppression, IL- $1 \alpha$, and IL-1 $\beta$ expression ${ }^{(50)}$.

In this study, the high clinical outcome of FC agree with the success rate of FC reported by other investigators ${ }^{(47,52,53)}$, but it is not in agreement with the outcomes of other studies ${ }^{(54,55)}$.

In the present study, the overall radiographic success rates for dHAM and FC groups were 100\% and $85 \%$, respectively. The radiographic success for amnion group agrees with the radiographic outcome of Prasad et al. ${ }^{(36)}$. Also, nearly similar radiographic outcomes for FC pulpotomy were reported by the study of Holan et al. ${ }^{(54)}$ and Salem and Farouk ${ }^{(56)}$ who recorded $83 \%$ and $87.5 \%$ success, respectively.

In this study, the only 3 radiographic failures recorded in formocresol group, were external root resorption, periapical radiolucency and furcal radiolucency. These results agree with the studies of Salem and Farouk ${ }^{(56)}$, Shabzendedar et al. ${ }^{(57)}$, and Olatosi et al. ${ }^{(58)}$.These radiographic failures may be due to seepage of the smaller size of the formocresol molecules into the periapical region via the pulpal canals or into the furcation area through the accessory canals or via the thin and permeable pulpal floor, which is a nature in primary molars ${ }^{(54)}$.

In the histopathological part of this study, the results revealed the ability of $\mathrm{dHAM}$ to enhance the rapid recovery of the radicular pulpal tissue, reduce inflammation and induce reparative dentinogenesis ${ }^{(36)}$. This can be attributed to its rich reservoirs of GFs and its immunosuppressive effect ${ }^{(59)}$. Another favourable property is the presence of
AM mesenchymal stromal cells that are multipotent cells capable of differentiating into cell lineages and generating different mesenchymal tissues ${ }^{(60-62)}$. Also, it is worth noting that In situ pulp injury studies have suggested that the lineage-restricted progenitor cells with apparent unipotency for osteodentine formation are the first to be differentiated into new odontoblast-like cells. Interestingly, these cells can be replenished by the more multipotent cells of the dHAM $^{(29,63)}$. This explains the osteodentin nature of the newly formed dentin bridge.

Furthermore, this primitive type of dentin acts as a type of pulp biomatrix that substitute the dental epithelium and basement membrane to provide the needed molecular induction of pulp cells differentiation into odontoblast-like cells ${ }^{(64,65)}$. This explains the presence of areas of active predentin formation adjacent to the Osteodentin Bridge ${ }^{(66)}$.

On the other hand, after one month, the pulp tissue of FC group showed signs of partial to complete loss of soft tissue organization, moderate to severe inflammation, loss of odontoblastic cell layer and signs of internal resorption ${ }^{(67)}$. Whereas severe pulp tissue destruction and extensive liquefaction necrosis were observed after 3-months interval ${ }^{(68,69)}$. The necrosis is induced by the release of hydrolytic enzymes from the necrotic neutrophils ${ }^{(70)}$. Neither 1 month nor 3 months intervals showed any signs of reparative dentiongenesis. These findings are comparable to those obtained by Talaat et al. ${ }^{(71)}$, ElMeligy et al. ${ }^{(72)}$ and Yorgancilar et al. ${ }^{(73)}$ who found that the formaldehyde within FC has an irritating effect that increases the infiltration of lymphomononuclear cells within the dental pulp. This augments dental pulp inflammatory responses that, in turn, stimulate the differentiation of odontoclasts and death of odontoblasts, which initiates internal inflammatory dentinal resorption and failure of dentin bridge formation, respectively ${ }^{(74-76)}$.

There is always an associated risk of infection transmission with transplantation of amniotic membranes. In this study, gamma irradiated 
dehydrated amniotic membrane was used, thus reducing any chances of cross infections. Adequate precautions should be taken and safety criteria should be included in the application of these biological membranes. Amniotic membranes are fragile.

Limitation of this study: The use of dHAM requires operator's experience, it is a sensitive technique, and it needs to be dealt with very carefully, as it is a fragile membrane.

\section{RECOMMENDATION}

Additional studies with more participants are needed to elucidate the histopathological significance to this clinical and radiographic study. Further long-term evaluations were mandatory to investigate the full potential of this stem cell reservoir on pulp tissue regeneration and confirming its biocompatibility, efficacy, and for the long-term prognosis of this novel allograft treatment method.

\section{CONCLUSION}

Dehydrated Human Amniotic Membrane with its favourable biological properties and its ability to stimulate growth factors has shown promising outcomes without any adverse effects in all pulpotomized teeth comparable to gold standard formocresol. So, it can be recommended as an alternative naturally derived pulpotomy agent in primary teeth pulpotomy.

\section{REFERRENCES}

1. Mythraiye R, Rao VV, Minor Babu MS, Satyam MP, Paravada C. Evaluation of the Clinical and Radiological Outcomes of Pulpotomized Primary Molars Treated with Three Different Materials: Mineral Trioxide Aggregate, Biodentine, and Pulpotec. An In-vivo Study. Cureus 2019; 11:e4803.

2. Prachi G, Pandit IK, Neeraj G, Monika G, Neha S, Vikas S. Clinical efficacy of various medicaments used for pulpotomy in primary molars - A comparative study. Int J Res Dev Pharm Life Sci 2016; 5:2107-2116.
3. Fuks A. Current concepts in vital primary pulp therapy. Eur J Paediatr Dent 2002; 3:115-120.

4. Maden M, Orhan O, Ertuğrul F, Sengüven B. The inflammatory response of the pulp after direct capping with platelet-rich plasma and enamel matrix derivative: A controlled animal study. OJST 2014; 4:14-21.

5. Kumar Praveen NH, Nayak Rashmi, Bhaskar Vipin K, Mopkar Pujan P. Pulpotomy Medicaments: Continued Search for New Alternatives- A Review. OHDM 2014; 13: 883-890

6. Gupta G, Rana V, Srivastava N, Chandna P. Laser Pulpotomy-An Effective Alternative to Conventional Techniques: A 12 Months Clinicoradiographic Study. Int J Clin Pediatr Dent 2015; 8: 18-21.

7. Somani R, Zaidi I, Jaidka S. Platelet rich plasma-A Healing aid and perfect Enhancement Factor: Review and Case Report. Int J Clin Pediatr Dent 2011; 4:69-75.

8. Keswani D, Pandey R, Ansari A, Gupta S. Comparative evaluation of platelet-rich fibrin and mineral trioxide aggregate as pulpotomy agents in permanent teeth with incomplete root development: a randomized controlled trial. J Endod 2014; 40:599-605.

9. Hiremath H, Saikalyan S, Kulkarni S, Hiremath V. Second-generation platelet concentrate (PRF) as a pulpotomy medicament in a permanent molar with pulpitis: a case report. Int Endod J 2012; 45:105-112.

10. Pogozhykh O, Prokopyuk V, Figueiredo C, Pogozhykh D. Placenta and Placental Derivatives in Regenerative Therapies: Experimental Studies, History, and Prospect. Stem Cells Int 2018; 2018: 14 pages.

11. Mohan R, Bajaj A, Gundappa M. Human amnion membrane: Potential applications in oral and periodontal field. J Int Soc Prevent Communit Dent 2017; 7:15-21.

12. Sane MS, Misra N, Quintanar NM, Jones CD, Mustafi SB. Biochemical characterization of pure dehydrated binate amniotic membrane: role of cytokines in the spotlight. Regen Med 2018; 13:689-703.

13. Kogan S, Sood A, Granick MS. Amniotic Membrane Adjuncts and Clinical Applications in Wound Healing: A Review of the Literature. Wounds 2018; 30:168-173.

14. Bhushan KS, Singh G, Chauhan G, Prakash S. Amniotic membrane \& its structure, features and uses in dentistry - a brief review. Int J Adv Res 2015; 3:354-360. 
15. Fukuda K, Chikama T, Nakamura M, Nishida T. Differential distribution of sub-chains of the basement membrane components type IV collagen and laminin among the amniotic membrane, cornea and conunctiva. Cornea 1999; 18:73-79.

16. Beddington RS, Robertson EJ. Axis development and early asymmetry in mammals. Cell 1999; 96:195-209.

17. Bryant-Greenwood GD. The extracellular matrix of the human fetal membranes: Structure and function. Placenta 1998; 19:1-11.

18. Malhotra C, Jain AK. Human amniotic membrane transplantation: Different modalities of its use in ophthalmology. World J Transplant 2014; 4:111-121.

19. Niknejad H, Peirovi H, Jorjani M, Ahmadiani A, Ghanavi $\mathrm{J}$, Seifalian AM. Properties of the amniotic membrane for potential use in tissue engineering. Eur Cell Mater 2008; 15:88-99.

20. Chen HJ, Pires RT, Tseng SC. Amniotic membrane transplantation for severe neurotrophic corneal ulcers. Br J Ophthalmol 2000; 84:826-833.

22. Davis JS. Skin transplantation. Johns Hopkins Hosp Rep 1910; 15:307-396.

23. Guler R, Ercan MT, Ulutuncel M, Devrim H, Uran N. Measurement of blood flow by the $133 \mathrm{Xe}$ clearance technique to grafts of amnion used in vestibuloplasty. Br J Obstet Gynaecol 1997; 35:280-283.

24. Kobayashi A, Sugiyama K, Li W, Tseng SC. In vivo laser confocal microscopy findings of cryopreserved and fresh human amniotic membrane. Ophthalmic Surg Lasers Imaging 2008; 39:312-318.

25. Memarzadeh F, Fahd AK, Shamie N, Chuck RS. Comparison of de-epithelialized amniotic membrane transplantation and conjunctival autograft after primary pterygium excision. Eye (Lond) 2008; 22:107-112.

26. Wen DY, Yuan J, Chen JQ. The application and biological improvement of amniotic membrane. Zhonghua Yan Ke Za Zhi 2006; 42:361-364.

27. Fernandes M, Sridhar MS, Sangwan VS, Rao GN. Amniotic membrane transplantation for ocular surface reconstruction. Cornea 2005; 24:643-653.

28. Prakasam S, Yim R, Hassan M. Dehydrated AmnionChorion Membranes for Periodontal and Alveolar Regeneration. JMDC 2017; 3:21-25.
29. Koob TJ, Rennert R, Zabek N, Massee M, Lim JJ, Temenoff JS, et al. Biological properties of dehydrated human amnion/chorion composite graft: implications for chronic wound healing. Int Wound J 2013; 10:493-500.

30. Allen CL, Clare G, Stewart EA, Branch MJ, McIntosh OD, Dadhwal M, et al. Augmented dried versus cryopreserved amniotic membrane as an ocular surface dressing. PLoS One 2013; 8:e78441.

31. Lullove EJ. Use of a Dehydrated Amniotic Membrane Allograft in the Treatment of Lower Extremity Wounds: A Retrospective Cohort Study. Wounds 2017; 29:346-351.

32. Chopra A, Thomas BS. Amniotic membrane: A novel material for regeneration and repair. J Biomim Biomater Tissue Eng 2013; 18:2-8.

33. Lakshmi S, Bharani S, Ambardar K. Repair of an oroantral communication by a human amniotic membrane: a novel technique. J Korean Assoc Oral Maxillofac Surg 2015; 41:194-197.

34. Fuks AB, Papagiannoulis L. Pulpotomy in primary teeth: review of the literature according to standardized criteria. Eur Arch Paediatr Dent 2006; 1:64-72.

35. Fuks A, Bimstein E, Klein H, Guelmann M. Assessment of a $2 \%$ buffered glutaraldehyde solution in pulpotomized primary teeth of school children. J Dent Child 1990;57:371 -375.

36. Prasad MG, Adiya PA, Babu DN, RadhaKrishna AN. Amniotic Membrane versus Formocresol as Pulpotomy Agents in Human Primary Molars: An in vivo Study. Pes-qui Bras Odontopediatria Clin Integr 2017; 17:e3794.

37. King SA, McWhorter AG, Seale NS. Concentration of formocresol used by pediatric dentists in primary tooth pulpotomy. Pediatr Dent 2002; 24:157-159.

38. Lee H, Shin Y, Kim SO, Lee HS, Choi HJ, Song JS. Comparative Study of Pulpal Responses to Pulpotomy with ProRoot MTA, RetroMTA, and TheraCal in Dogs' Teeth. J Endod 2015; 41:1317-1324.

39. Hasheminia SM, Feizi G, Razavi SM, Feizianfard M, Gutknecht N, Mir M. A comparative study of three treatment methods of direct pulp capping in canine teeth of cats: A Histologic evaluation. Lasers Med Sci 2010; 25:9-15.

40. Songsiripradubboon S, Banlunara W, Sangvanich P, Trairatvorakul $\mathrm{C}$, Thunyakitpi $\mathrm{P}$. Clinical, radiographic, and histologic analysis of the effects of acemannan used in direct pulp capping of human primary teeth: short-term outcomes. Odontology 2016; 104:329-337. 
41. Petrović V, Pejčić N, Čakić S. The Influence of Different Therapeutic Modalities and Platelet Rich Plasma on Apexogenesis - a Preliminary Study in Monkeys. Adv Clin Exp Med 2013; 22: 469-479.

42. Güneş M, Altok M, Ozmen O, Umul M, Güneş A, Baş E, et al. A Novel Experimental Method for Penile Augmentation Urethroplasty With a Combination of Buccal Mucosa and Amniotic Membrane in a Rabbit Model. Urology 2017; 102:240-246.

43. Alshehadat SA, Thu HA, Hamid SA, Nurul AA, Rani SA, Ahmad A. Scaffolds for dental pulp tissue regeneration: A review. Int Dent Med J Adv Res 2016; 2:1-12.

44. Rosen PS. Case report on combination therapy using a composite allograft containing mesenchymal cells with an amnion-chorion barrier to treat a mandibular class III furcation. Clin Adv Periodontics 2013; 3:64-69.

45. Godhi B, Sood PB, Sharma A. Effects of mineral trioxide aggregate and formocresol on vital pulp after pulpotomy of primary molars: An in vivo study. Contemp Clin Dent 2011; 2:296-301.

46. Koob TJ, Lim JJ, Massee M, Zabek N, Denozière G. Properties of dehydrated human amnion/chorion composite grafts: implications for wound repair and soft tissue regeneration. J Biomed Mater Res B Appl Biomater 2014; 102:1353-1362.

47. El Meligy OA, Alamoudi NM, Allazzam SM, ElHousseinyAA. BiodentineTM versus formocresol pulpotomy technique in primary molars: a 12-month randomized controlled clinical trial. BMC Oral Health 2019; 19:3. doi: 10.1186/s12903-018-0702-4.

48. Liu PF, Guo L, Zhao DW, Zhang ZJ, Kang K, Zhu RP, et al. Study of human acellular amniotic membrane loading bone marrow mesenchymal stem cells in repair of articular cartilage defect in rabbits. Genet Mol Res 2014; 13:79928001 .

49. Niknejad H, Peirovi H, Jorjani M, Ahmadiani A, Ghanavi J, Seifalian AM. Properties of the amniotic membrane for potential use in tissue engineering. Eur Cell Mater 2008; 15:88-99.

50. Solomon A, Rosenblatt M, Monroy D, Ji Z, Pflugfelder SC, Tseng SC. Suppression of interleukin 1alpha and interleukin 1beta in human limbal epithelial cells cultured on the amniotic membrane stromal matrix. Br J Ophthalmol 2001; 85:444-449.
51. Chen E, Tofe A. A literature review of the safety and biocompatibility of amnion tissue. J Implant Adv Clin Dent 2010; 2: 67-75.

52. Farsi N, Alamoudi N, Balto K, Mushayt A. Success of mineral trioxide aggregate in pulpotomized primary molars. J Clin Pediatr Dent 2005; 29:307-311.

53. Sonmez D, Sari S, Cetinbas T. A comparison of four pulpotomy techniques in primary molars: a long-term follow-up. J Endod 2008; 41:547-555.

54. Holan G, Eidelman E, Fuks A. Long-term evaluation of pulpotomy in primary molars using mineral trioxide aggregate or formocresol. Pediatr Dent 2005; 27:129-136.

55. Jabbarifar S, Khademi A, Ghasemi D. Success rate of formocresol versus mineral trioxide aggregate in human primary molar tooth. J Res Med Sci 2004;6:55-58.

56. Salem GA, FaroukYM. Clinical and radiographic evaluation of testing different concentrations of sodium hypochloride as vital pulpotomy treatment in primary teeth: a randomized controlled trial. J Arab Soc Med Res 2017;12;106-112.

57. Shabzendedar M, Mazhari F, Alami M, Talebi M.Sodium hypochlorite vs formocresol as pulpotomy medicaments in primary molars: 1-year follow-up. Pediatr Dent. 2013;35:329-32.

58. Olatosi O, Sote E, Orenuga O. Effect of mineral trioxide aggregate and formocresol pulpotomy on vital primary teeth. Niger J Clin Pract 2015; 18:292-296.

59. Park CY, Kohanim S, Zhu L, Gehlbach PL, Chuck RS Immunosuppressive Property of Dried Human Amniotic Membrane. Ophthalmic Res 2009; 41: 112-113.

60. Parolini O, Alviano F, Bagnara GP, Bilic G, Bühring $\mathrm{HJ}$, Evangelista M, et al. Concise review: isolation and characterization of cells from human term placenta: outcome of the first international Workshop on Placenta Derived Stem Cells. Stem Cells 2008; 26:300-311.

61. Ilancheran S, Michalska A, Peh G, Wallace EM, Pera M, Manuelpillai U. Stem cells derived from human fetal membranes display multilineage differentiation potential. Biol Reprod 2007; 77:577-588.

62. Heckmann N, Auran R, Mirzayan R. Application of Amniotic Tissue in Orthopedic Surgery. Am J Orthop (Belle Mead NJ) 2016; 45:E421-E425.

63. Lee CP, Colombo JS, Ayre WN, Sloan AJ, Waddington RJ. Elucidating the cellular actions of demineralised 
dentine matrix extract on a clonal dental pulp stem cell population in orchestrating dental tissue repair. J Tissue Eng 2015;6:2041731415586318. doi: 10.1177/2041731415586318. eCollection 2015.

64. Lesot H, Smith AJ, Tziafas D, Begue-Kirn C, Cassidy N, Ruch JV. Biologically active molecules and dental tissue repair: a comparative review of reactionary and reparative dentinogenesis with the induction of differentiation in vitro. Cell Mater 1994;4:199-218.

65. Tziafas D. Reparative dentinogenesis. A Monograph on the Dentinogenic Potential of the Pulp. Thessaloniki, Greece: University Studio Press. 1997.

66. Tziafas D, Pantelidou O, Alvanou A, Belibasakis G, Papadimitriou S. The dentinogenic effect of mineral trioxide aggregate (MTA) in short-term capping experiments. Int Endod J. 2002; 35:245-254.

67. Haghgoo R, Abbasi F. A histopathological comparison of pulpotomy with sodium hypochlorite and formocresol. Iran Endod J. 2012; 7: 60-62.

68. Block RM, Lewis RD, Hirsch J, Coffey J, Langeland K. Systemic distribution of 14C-labeled paraformaldehyde incorporated within formocresol following pulpotomies in dogs. J Endod 1983; 9: 176-189.

69. Cleaton-Jones P, Duggal M, Parak M, William S, Setze S. Ferric sulphate and formocresol pulpotomies in baboon primary molars: histological responses. Eur J Paediatr Dent 2002; 3: 121-125.

70. Robins, Cotran. Pathologic basis of disease. 8th Ed. Philadelphia, WB Saunders Co. 2010: 15.

71. Talaat DM, Matar M, Nagui D. Histological Evaluation of Pulpotec Effect on Pulpotomized Primary Teeth in Puppies. OHDM 2014; 13:295-299.

72. El-Meligy O, Abdalla M, El-Baraway S, El-Tekya M, Dean JA. Histological evaluation of electrosurgery and formocresol pulpotomy techniques in primary teeth in dogs. J Clin Pediatr Dent 2001; 26:81-85.

73. Yorgancilar E, Deveci E, Deveci S. Effects of Formaldehyde on Respiratory Mucosa in Rats. Int J Morphol 2012; 30:521-523.

74. Toomarian L, Fekrazad R, Sharifi D, Baghaei M, Rahimi H, Behnam E. Histopathological evaluation of pulpotomy with Er,Cr:YSGG laser vs Formocresol. Lasers Med Sci 2008; 23: 443-450.

75. Maria R, Mantri V, Koolwal LS. Internal resorption: A review \& case report. Endodontology 2010; 22:100-108.

76. Haapasalo M, Endal U. Internal inflammatory root resorption: the unknown resorption of the tooth. Endod Topics 2008; 14:60-79. 